Reviews in Digital Humanities • Vol. 2, No. 5

\title{
Review: Land and Legacy
}

Claire A. Tratnyek ${ }^{1}$

${ }^{1}$ Northeastern University

Published on: May 10, 2021

DOI: $10.21428 / 3 e 88 f 64 f .700222 b 0$

License: Creative Commons Attribution 4.0 International License (CC-BY 4.0). 


\section{Project}

Land and Legacy

\section{Project Directors}

Janet S. Dunkelbarger, University of Virginia

Connor Kenaston, University of Virginia

Natasha Roth-Rowland, University of Virginia

Lauren Van Nest, University of Virginia

Chloe Down Wells, University of Virginia

\section{Project URL}

https://landandlegacy.scholarslab.org/

\section{Project Reviewer}

Claire A. Tratnyek, Northeastern University

\section{Project Overview}

\section{Janet S. Dunkelbarger, Connor Kenaston, Natasha Roth-Rowland, Lauren Van Nest, and Chloe Down Wells}

Land and Legacy investigates the land development and expansion of the University of Virginia (UVA) and University of Virginia Foundation (UVAF) throughout

Charlottesville, Virginia and Albemarle County, Virginia since the 1980s. The project focuses on how these changes have affected local communities, reshaped city and county topography, and contributed to local inequities. At the center of the project are three sequential stories titled "Foundations," "Investment," and "Legacy." These stories describe the conditions that led to UVA's embrace of real estate investment and the creation of the UVAF; how UVA and the UVAF's acquisitions have frequently conflicted with their stated institutional goals and values; and the problematic ripple effects of UVA's desire to link its institutional and architectural identity with a relatively uncritical presentation of its "Jeffersonian" heritage.

\section{Team and Background}

Land and Legacy was created by the 2019-2020 Praxis Program fellows, all doctoral students at the University of Virginia: Janet S. Dunkelbarger, Connor Kenaston, Natasha Roth-Rowland, Lauren Van Nest, and Chloe Downe Wells. Based at the Scholars' Lab at the UVA Library, the fellows received training in digital methods and 
tools, and they collaborated to create a digital humanities project. In addition to the guidance and assistance provided by the Scholars' Lab staff, the project team also consulted with library staff, researchers working on the Charlottesville Equity_Atlas, and other members of the UVA and Charlottesville community.

Land and Legacy reflects the perspectives of its makers, who are simultaneously employees of the university and members of the Charlottesville community. The project brings university, city, and county data and narratives together in a public and accessible digital space to speak to the project's primary audiences: the overlapping communities of Charlottesville, Albemarle County, and the university. By demonstrating the tension between a public university's claims to operate for the "public good" and the effects of its real estate practices, Land and Legacy contributes to the growing field of critical university studies.

\section{Development Process}

Land and Legacy initially began as an ArcGIS project that used city and county records and parcel data to visualize UVA's real estate practices over time. ArcGIS data enabled the team to track UVA's acquisition of land and moments of intense building activity. They soon realized, however, that the maps they had created made UVA's growth seem natural and uncontested. They adopted ArcGIS StoryMaps to integrate maps and other visual media with necessary context and stories of resistance. In addition to analyzing tabular and spatial data, the team also examined newspapers, reports by university presidents, changes in the UVAF website via the Wayback Machine, and meeting minutes and plans from various arms of the university tasked with real estate, urban planning, architecture, and memorialization. The team used these sources to demonstrate the conflict between the rhetoric the university employed to describe its real estate and naming practices and the actual impacts those practices have had on local communities.

\section{Assessment and Engagement}

Land and Legacy builds on existing digital resources surrounding real estate, racial equity, and history in the Charlottesville region. The team decided to build a website with the layout, image resolution, and overall appearance tested for maximum accessibility, in order to encourage and facilitate public engagement, as well as to create additional space for acknowledging the people and projects that contributed to its own work. Building a website also allowed for easy access to the team's data that informed the stories. The StoryMaps were embedded using iframes to make viewing 
the project as straightforward as possible. The website also contains a "Future Directions" page to propose policy recommendations and avenues for future research.

\section{Project Review}

\section{Claire A. Tratnyek}

As of May 2020, the University of Virginia (UVA) and the UVA Foundation (UVAF) together own and/or occupy $4 \%$ of the land in Charlottesville, Virginia (about 257 acres) and over 1\% of the land in Albemarle County, Virginia (about 6,106 acres). Before UVA's founding in 1819 by Thomas Jefferson, Anglo-American farmers occupied the land the university stands on, and before that the land was stewarded by the Monacan Indian Nation. A cornerstone was laid in 1817, the first phase of building continued until 1826, and other expansions were undertaken at various points in the university's history - several of which have significantly expanded the university's footprint in the area since 1980. Land and Legacy examines how land development and expansion projects since the 1980s have affected the local communities, and how the narratives UVA promotes publicly - like their "Great and Good" 2030 strategic plan — are connected with these kinds of expansion.

Land and Legacy was created by a group of UVA graduate students who participated in the UVA Library's Scholars' Lab Praxis Program during the 2019-2020 school year. Each year, Praxis Fellows are given intensive training in digital humanities tools and methods and spend the spring semester working collaboratively to design and launch a digital humanities project or piece of software. Land and Legacy builds on Augmenting the University, a previous Praxis AR modeling project, as well as the Charlottesville Regional Equity Atlas, a collaboration among the Scholars' Lab, the Library, and local partners. Each cohort of Praxis Fellows also blogs about the development of their projects (and other, related research they're undertaking) on the Scholars' Lab blog. The 2019-2020 Praxis Fellows embraced an interdisciplinary approach to assembling their data set for Land and Legacy, which includes GIS data from the UVA Library, open-source data from the city of Charlottesville and the state, archival images and texts, meeting minutes, local and university newspapers, and property records from the university and community. The team used ArcGIS StoryMaps to create the project and included links to their data sources and to other related digital projects in the "Additional Resources" section. The project is clearly organized, and its interface is easily navigable. 
The project is divided into three sequential narrative history "stories" to tackle three distinct categories of the Praxis Fellows' research questions. The first, "Foundations," lays out the scope of the entire project, and the goal to engage with questions of "land, space, race, and power" in the Charlottesville area in the recent past and today. The team enumerates their research questions, which go beyond scrutinizing the intricacies of "town and gown" relationships among school, students, and community to engage with national-level conversations about the use of space to commemorate, to promote equity, and to contribute to the public good. This section chronicles the interactions among the university, the UVA Real Estate Foundation (later the UVAF), the city government and community of Charlottesville, and Albemarle County in the 1980s, when the school's largest expansion endeavors began - and when the local community began to push back against them.

At the top of this story is an animated GIF map that shows annual expansion from the 18th century to 2020 as color-coded polygons. Though it clearly illustrates the scope of the school's expansion, especially since the latter half of the twentieth century, it speeds along and isn't explicitly linked to the narrative, which does contextualize in detail each parcel of land and development project. Individual or short-sequence maps would be a welcome addition to the narrative and would tie back to the otherwise impressive mother map.

The second story, "Investment," picks up in the 1990s and early 2000s, when the university and the UVAF saw real estate acquisition and development as an essential component for the university's financial stability. The Praxis Fellows situate their analysis of the UVA's real estate activities within the context of neoliberal economic practices, and look, again, to the community surrounding the school for their reactions to both the expansion and to the school's promotion and framing of their expansion endeavors as "neighborly" activities. The four case studies in this section, Emmet/Ivy Corridor, The Boar's Head, Brandon Avenue/South Lawn, and the UVA Research Park, each grapple with questions of finance, benefit, ownership, contested spaces, and perception in different ways; all circle back to the UVA 2030 Strategic Plan and the driving question of how the university can achieve greatness and goodness as a neighbor and community member while also seeking to profit off its properties. The third section and story, "Legacy," engages with the questions around Thomas Jefferson's - and the university's - legacy and the landscape of commemoration on an active academic campus, as well as in an urban center. Here, the team contrasts the lionization of Jefferson with the erasure of enslaved and free Black people in the UVA landscape. They revive the "Canada" community of the 19th century, a majority-Black 
community first camouflaged and then subsumed by the university, and make connection to other area projects that endeavor to introduce the UVA and Charlottesville communities to lesser-known stories and lives in the area's past.

The Praxis Fellows conclude their project with a section, "Future Directions," that reiterates their findings: although UVA and UVAF leadership presented expansion projects as neighborly investments into the community, those beneficent goals often conflicted with the actual practice of development, which materially harmed and displaced some local communities. They lay out recommendations for both the university and the UVAF and identify several avenues for future research. The creators of this project clearly see it situated among others that investigate the deep and interconnected histories of places, but also in conversation with current and ongoing research into race and place, commemorative landscapes and contested spaces, and the ways in which large, ostensibly "public" organizations like the University of Virginia, relate to and engage with the communities they occupy. In both form and content, Land and Legacy is an exemplar of collaborative research and the integration of digital and traditional historical methods. As scholars and citizens across the United States continue to uncover and confront the difficult histories of our localities, this kind of project can provide us with new vocabularies for interdisciplinary thinking and integrated storytelling - without sacrificing rigor or eliding uncomfortable questions. 